\title{
Oxidative Stress Gated by Fenton and Haber Weiss Reactions and Its Association With Alzheimer's Disease
}

\author{
Tushar Kanti Das ${ }^{1}$; Mas Rina Wati ${ }^{1}$; Kaneez Fatima-Shad ${ }^{2,}$ \\ ${ }_{1}^{1}$ PAPRSB Institute of Health Sciences, UniversitI Brunei Darussalam, Brunei Darussalam, Brunei \\ ${ }^{2}$ School of Medical and Molecular Biosciences, Faculty of Science, University Technology Sydney, Sydney, Australia \\ ${ }^{*}$ Corresponding author: Kaneez Fatima-Shad, School of Medical and Molecular Biosciences, Faculty of Science, University Technology Sydney, Sydney, Australia. Tel: +614320644886, \\ E-mail: KaneezFatima-Shad@uts.edu.au
}

Received: May 29, 2014; Revised: Jun 15, 2014; Accepted:Jun 17, 2014

\begin{abstract}
Context: Involvement of reactive oxygen species (ROS) in a variety of physiological and pathological processes has attracted a growing interest. In fact, identification of this global signaling system has provided new insights into underlying pathophysiological mechanisms of various diseases such as Alzheimer's disease (AD). Understanding this information may lead to the development of novel therapeutic strategies.

Evidence Acquisitions: Limited efficacy of current medications for neurological disorders and dementias such as AD has led to considerable research interests in new drug development. Based on the modulatory effects of the Fenton reactions with transition metals such as iron, copper, zinc and aluminum on ROS and the effect of free radicals on neuroinflammatory and neurodegenerative processes, we hypothesized that pharmacological manipulation of the transition metals gated hydroxyl ion might be beneficial in treating neurological disorders such as AD.

Results: Catalytic activities of transition metals gated by the Fenton reactions are involved in the survival and pathological signaling pathways, neural plasticity, and neuroprotection. Furthermore, ROS and RNS have proved to exhibit overwhelming pathological effects leading to a variety of neurological disorders.

Conclusions: In the present investigation, an overview was made on regulatory role of the Fenton reaction gated catalytic activities of transition metals and some evidence regarding their mechanisms leading to Alzheimer's disease. Based on the neuroinflammatory and neurodegenerative effects of transition metals, drugs with antagonizing effects could be a promising therapeutic alternative for Alzheimer's disease.
\end{abstract}

Keywords:Fenton Haber Weiss Reactions; Reactive Oxygen Species; Metals; Alzheimer's disease

\section{Context}

The Fenton and Haber Weiss reaction plays a significant role in oxidative stress causing numerous degenerative diseases such as Alzheimer's disease (AD). Reactive oxygen species (ROS) and reactive nitrogen species (RNS) are produced by the reaction causing oxidative stress in AD. Iron, copper and aluminum promote the formation of free radicals such as Hydroxyl radicals causing damage to DNA, proteins, lipids and carbohydrates. Hydroxyl radicals produced by Fenton reaction, causes the A $\beta 42$ toxicity $(1,2)$ in AD. Hydroxyl radicals can be produced in the presence of Ferric ions and converts soluble human fibrinogen into an insoluble fibrin- like aggregate observed in neurodegenerative diseases such as AD (3). DNA bases can be modified by the Fenton gated oxidative stress and base substitutions $\mathrm{G} \rightarrow \mathrm{C}$ (in the presence of Ferrous), G $\rightarrow$ T and $\mathrm{C} \rightarrow \mathrm{T}$ (Copper and Nickel) (4) by the reaction with ROS. Signal transduction molecules, such as extracellular signal-regulated kinase 1 and 2 (ERK1/2), c-Jun N -terminal kinase (JNK), phosphoinositide 3 - kinase (PI3K), p38 and transcription factors such as activator protein-1(AP-1), and p53 are activated by ROS (4, 5). Hydroxyl radicals can damage DNA by p53 pathway and accelerate AD development. Mutation in tumor suppressor gene (TP53) is associated with AD pathogenesis $(2,6)$.

Oxidative stress is mainly produced by the Fenton reaction by removal of one electron from the molecular oxygen $\left(\mathrm{O}^{2}\right)$ results in the formation of superoxide $\left(\mathrm{O}^{2-}\right.$ ) which often produces other ROS species such as $\mathrm{H}_{2} \mathrm{O}_{2}$ and Peroxynitrite (ONOO)-and hydroxyl radicals $(\mathrm{OH})$ (7). However under normal conditions, $\mathrm{O}^{2-}$ has been emerged as an important signaling molecule, which controls specific biochemical reactions and metabolic processes (8). The link between $\mathrm{O}^{2-}$ production and $\mathrm{H}_{2} \mathrm{O}_{2}$ can involve a reduced flavin enzyme, which transfers an electron to activate molecular oxygen into superoxide which either released or enzymatically converted into $\mathrm{H}_{2} \mathrm{O}_{2}(9,10)$ or modified by drugs such as statins (11).

One of the greatest challenges in the field of ROS-gated diseases is to bridge the knowledge gap between atomic 
and cellular level, and more understanding of the Fenton reaction may help to bridge this gap. In 1890, Fenton used a solution of $\mathrm{H}_{2} \mathrm{O}_{2}$ and Iron to oxidized contaminants of waste water. When transient metals such as iron react with hydrogen peroxide $\left(\mathrm{H}_{2} \mathrm{O}_{2}\right)$, it produces Ferric $\left(\mathrm{Fe}^{+++}\right)$, hydroxyl radical and hydroxyl ion $\left(\mathrm{OH}^{-}\right)$. Hydroxyl ion $\left(\mathrm{OH}^{-}\right)$reacts with $\mathrm{H}_{2} \mathrm{O}_{2}$ again to produce superoxide and hydroxyl ion $\left(\mathrm{OH}^{-}\right)$.

Reactive oxygen species (ROS) are produced as the byproduct of the electron transport chain (ETC) in mitochondria and are responsible for lipid peroxidation, protein oxidation, DNA damage and advanced glycation end-products (AGEs) formation via effects of ROS on cellular signaling pathways.

\section{Evidence Acquisitions}

\subsection{Oxidative Stress and $A D$}

Our early work on the effect of herbs on ROS (12-14) genes mutation in $\mathrm{AD}$ (15), effect of metals on gene modification in psychiatric disorders (16) and effect of ROS on neurological disorders (17) indicate underlying importance of the Fenton reaction. We searched any evidence (18-21) responsible for AD pathogenesis.

\subsection{Fenton and Haber-Weiss Chemistry}

Since brain is the most aerobically active organ in the body, ROS is mostly produced in the brain. Iron (Fe), copper ( $\mathrm{Cu})$, zinc ( $\mathrm{Zn})$ and aluminum (Al), due to their multiple valence states can react with the molecular oxygen and produce ROS and RNS. The Fenton and Haber-Weiss reaction has a significant role in ROS production and $\mathrm{AD}$ pathogenesis. The Fenton reaction is defined as the reaction of ferrous iron $\left(\mathrm{Fe}^{2+}\right)$ and hydrogen peroxide $\left(\mathrm{H}_{2} \mathrm{O}_{2}\right)$. In this reaction, ferric iron $\left(\mathrm{Fe}^{3+}\right)$ and hydroxyl radical are produced. Then hydroxyl radical reacts with $\mathrm{H}_{2} \mathrm{O}_{2}$ and superoxide $\left(\mathrm{O}_{2}^{-}\right)$is produced. Then superoxide reacts again with $\mathrm{H}_{2} \mathrm{O}_{2}$, hydroxyl radical and hydroxyl anion $(-\mathrm{OH})$ are formed; this part of reaction is known as the "Haber-Weiss Reaction". Superoxide $\left(\mathrm{O}_{2}^{-}\right)$reduces to $\mathrm{Fe}^{3+}$ rather than $\mathrm{H}_{2} \mathrm{O}_{2}$. The overall reaction is represented as follows;

$$
\begin{aligned}
\mathrm{Fe}^{+2}+\mathrm{H}_{2} \mathrm{O}_{2} \rightarrow \mathrm{Fe}^{+3}+\mathrm{OH}+{ }^{-} \mathrm{OH} \text { [Fenton reaction] } \\
\mathrm{OH}+\mathrm{H}_{2} \mathrm{O}_{2} \rightarrow \mathrm{O}_{2}{ }^{-}+\mathrm{H}++\mathrm{H}_{2} \mathrm{O} \\
\quad \mathrm{Fe}{ }^{+3} / \mathrm{Fe}^{+2} \\
\mathrm{O}_{2}{ }^{-}+\mathrm{H}_{2} \mathrm{O}_{2} \stackrel{\mathrm{OH}+\mathrm{OH}^{-}+\mathrm{O}_{2} \text { [Haber-Weiss reaction] }}{\longrightarrow}
\end{aligned}
$$

Several metals such as $\mathrm{Fe}, \mathrm{Cu}, \mathrm{Zn}$ and $\mathrm{Al}$ have oxygentransferring properties for the catalytic power to generate highly reactive $\bullet \mathrm{OH}$ by the Fenton reaction. $\bullet \mathrm{OH}$ is the most powerful oxidant for the oxidative stress in
$\mathrm{AD}$. $\bullet \mathrm{OH}$ is mainly involved in three types of reaction as hydrogen abstraction, addition reaction and oxidation reaction.

$$
\begin{aligned}
& \mathrm{R}-\mathrm{H}+{ }^{\circ} \mathrm{OH} \rightarrow \mathrm{R} .+\mathrm{H}_{2} \mathrm{O} \text { [hydrogen abstraction reaction] } \\
& \mathrm{R}_{4} \mathrm{C}_{2}+{ }^{\circ} \mathrm{OH} \rightarrow \mathrm{R}_{2}-\mathrm{C}(\mathrm{OH})-\mathrm{C} \cdot-(\mathrm{R})_{2} \text { [addition reaction] } \\
& \mathrm{M}^{+}+{ }^{\cdot} \mathrm{OH} \rightarrow \mathrm{M}^{(\mathrm{n} 1+)}+\mathrm{OH}^{-} \text {[oxidation reaction] }
\end{aligned}
$$

\subsection{Metals Causing Oxidative Stress in $A D$}

\subsubsection{Iron in $A D$}

Iron has a pivotal role in oxidative stress by the formation of hydroxyl radical through Fenton reaction in $\mathrm{AD}$ pathogenesis. $\mathrm{Fe}^{2+}$ is oxidized to $\mathrm{Fe}^{3+}$ by oxygen molecule $\left(\mathrm{O}_{2}\right), \mathrm{O}_{2}{ }^{-}$is produced. $\mathrm{O}_{2}{ }^{-}$Reacts with hydrogen ion $\left(\mathrm{H}^{+}\right)$and $\mathrm{H}_{2} \mathrm{O}_{2}$ is produced. Then $\mathrm{H}_{2} \mathrm{O}_{2}$ reacts with $\mathrm{Fe}^{2+}$ and $\bullet \mathrm{OH}$ is produced by the Fenton reaction. Then $\bullet \mathrm{OH}$ is produced again by the reaction of hydrogen peroxide in the presence of $\mathrm{Fe}^{3+} / \mathrm{Fe}^{2+}$ via the Haber-Weiss reaction.

Lovell et al. in 1998 found that Fe concentration in AD plaques ( $\sim 1 \mathrm{mmoL} \mathrm{L}-1)$ is more than normal brain tissue $(\sim 350 \mu \mathrm{mol} \mathrm{L}-1)(22)$. In vitro studies also showed that Fe induces $\mathrm{A} \beta$ aggregation (23) and tau phosphorylation (24).

\subsubsection{Copper in $A D$}

Copper $(\mathrm{Cu})$ is also an important catalyst for production of ROS. $\mathrm{Cu}$ can bind with $\mathrm{A} \beta$ peptide, this $\mathrm{Cu}-\mathrm{A} \beta$ peptide can produce $\mathrm{H}_{2} \mathrm{O}_{2}$ through reduction of $\mathrm{Cu}^{+2}$ to $\mathrm{Cu}^{+}$and subsequently hydroxyl radical $(\bullet \mathrm{OH})$ is produced, which increases oxidative stress and causes neuronal death (25). $A \beta$ is converted to $A \beta$. as a result $A \beta$ exhibits the greatest activity of $A \beta$ aggregation in $A D$ pathogenesis (26). $A \beta$ can also cause lipid protein oxidation and 4-hydroxy- 2-nonenal (HNE) carbonyl is produced.

$$
\begin{aligned}
& \mathrm{Cu}^{+2}+\mathrm{A} \beta \text { Met }(\mathrm{S}) \rightarrow \mathrm{A} \beta \text { Met }\left(\mathrm{S}^{+}\right)+\mathrm{Cu}^{+} \\
& \mathrm{Cu}^{+}+\mathrm{O}_{2} \rightarrow \mathrm{Cu}^{+2}+\mathrm{O}_{2}^{-} \\
& \mathrm{O}_{2}^{-}+\mathrm{O}_{2}^{-}+2 \mathrm{H}+\rightarrow \mathrm{H}_{2} \mathrm{O}_{2} \\
& \mathrm{Cu}++\mathrm{H}_{2} \mathrm{O}_{2} \rightarrow \mathrm{Cu}^{+2}+{ }^{-} \mathrm{OH}+{ }^{-} \mathrm{OH} \text { [Fenton reaction] } \\
& \mathrm{Cu}^{2+}+\mathrm{A} \beta \rightarrow \mathrm{A} \beta+\mathrm{Cu}^{+} \\
& \mathrm{A} \beta+\text { Lipid protein } \rightarrow \text { HNE Carbonyl }+\mathrm{A} \beta
\end{aligned}
$$

Activity of cytochrome C- oxidase (27), copper/zinc peroxidase (28) and ceruloplasmin (29) are diminished by free radicals. Lower level of ceruloplasmin may increase lipid peroxidation (30). Reduction of $\mathrm{Cu}^{+2}$ to $\mathrm{Cu}^{+}$by $\mathrm{A} \beta$ 
enhances oxidative stress by the production of $\bullet \mathrm{OH}$ and further neuronal damage in $\mathrm{AD}$ (31). Interaction of $\mathrm{Cu}$ with tau peptide may also induce neurofibrillary tangles (32). In vitro studies revealed that $\mathrm{Cu}^{2+}$ and $\mathrm{Zn}^{2+}$ promote neurotoxicity by the generation of $\mathrm{H}_{2} \mathrm{O}_{2}$ (33, 34). Literature indicated that $\mathrm{A} \beta-\mathrm{Cu}^{2+}$ stimulates ROS production $(33,35)$ by the Fenton and Haber-Weiss reaction, causing oxidative stress and AD.

\subsubsection{Zinc in $A D$}

Zn binds to $A \beta$. Zn-A $\beta$ complex is transiently stable prior to aggregation $(36,37)$ and contains less fibril $(38)$. When $\mathrm{Zn}$ binds to $\mathrm{A} \beta$-peptide via histidine residues, then $\mathrm{Zn}-\mathrm{A} \beta$ complex changes their conformation and copper cannot bind to $A \beta$. In this way, $\mathrm{Zn}$ can prevent $\mathrm{Cu}-\mathrm{A} \beta$ induced $\mathrm{H}_{2} \mathrm{O}_{2}$ and free radicals. The possible mechanism might be due to its competition with $\mathrm{Cu}$ or Fe. Low concentration of $\mathrm{Zn}$ protects $\mathrm{A} \beta$ toxicity, but excessive $\mathrm{Zn}$ causes neuronal death by the oxidation independently or synergistically. Higher concentration of $\mathrm{Zn}^{2+}$ binds to $\mathrm{A} \beta$ and precipitates at pH 6-8 (39).

\subsubsection{Aluminum in $A D$}

Aluminum ( $\mathrm{Al})$ can accelerate oxidative stress in vivo and in vitro (40). Aluminum superoxide semireduced radical ions $\left(\mathrm{AlO}_{2}{ }^{2+}\right)$ are produced by the reaction of $\mathrm{Al}^{3+}$ with superoxide $\left(\mathrm{O}_{2}^{-}\right)$. $\mathrm{AlO}_{2}^{2+}$ then reduces $\mathrm{Fe}^{3+}$ to $\mathrm{Fe}^{2+}$ and promotes the oxidative stress through the Fenton and Haber-Weiss reaction (41-43).

\subsection{DNA Damage}

Hydroxyl radical $(\bullet \mathrm{OH})$ plays a critical role in nucleic acids damage (44). It is produced by the Fenton reaction. $\bullet \mathrm{OH}$ can react with DNA by either hydrogen abstraction or addition reaction. When hydroxyl radical reacts in hydrogen abstraction, leading to disruption of DNA strand and when hydroxyl radical takes part in addition reaction, then deoxyguanosine is converted to 8-hydroxy deoxyguanosine (8-OHdG) ( Figure 1) (45).

$\mathrm{OH}+\mathrm{DNA} \rightarrow$ DNA strand breaks [hydrogen abstraction] 5-hydroxymethyluracil and hydroxyadenine are produced by the reaction of ROS with thymine and adenine respectively (46). In oxidative deamination, $\mathrm{NH} 2$ group is substituted by -OH group of Nucleic acid. As a result, adenine cytosine and guanine are transformed to hypoxanthine, uracil and xanthine, respectively. Therefore, deamination of DNA can cause in GC $\rightarrow$ AT transition in oxidative stress $(47,48)$.

Purine and pyrimidine bases can produce 20 different oxidative products of DNA with the interaction of $\bullet \mathrm{OH}$ (49). 8-hydroxyguanine, 8-Hydroxyguanosine (8OHG), 8-hydroxyadenine, thymine glycol, Fapy-guanine, 5-hydroxyuracil and Fapy-adenine are major products of DNA oxidation by the reaction of ROS and RNS (50) found in parietal, temporal, occipital, frontal lobe, su- perior temporal gyrus, hippocampus of brains of patients with AD (51). It is indicated that DNA damage is performed by the Fenton reaction in $\mathrm{AD}$ pathogenesis.

\subsection{Lipid Peroxidation}

Due to the presence of double bonds, polyunsaturated fatty acid, is highly reactive towards free radicals mainly hydroxyl radical. Two reaction mechanisms are proposed for lipid peroxidation as hydroxyl radical dependent and hydroxyl independent. $\mathrm{Fe}^{2+}$ acts as a positive catalyst for the production of hydroxyl radical dependent lipid peroxidation.

Hydroxyl radical dependent mechanism:

$\mathrm{Fe}^{+2}+\mathrm{H}_{2} \mathrm{O}_{2} \rightarrow \mathrm{Fe}^{+3}+{ }^{\circ} \mathrm{OH}+{ }^{-} \mathrm{OH}$ [The Fenton and Haber-Weiss reaction]

Hydroxyl independent mechanism:

$$
\begin{aligned}
& \mathrm{Fe}^{+2}+\mathrm{O}_{2} \rightarrow\left[\mathrm{Fe}^{+2}-\mathrm{O}_{2} \leftrightarrow \mathrm{Fe}^{+3}-\mathrm{O}_{2}^{-}\right] \rightarrow \mathrm{Fe}^{+3}+\mathrm{O}_{2}^{-} \\
& \mathrm{Fe}^{+3}+\mathrm{O}_{2}^{-} \rightarrow \mathrm{O}_{2}+\mathrm{Fe}^{+2} \\
& \mathrm{Fe}^{+2}+\mathrm{H}_{2} \mathrm{O}_{2} \rightarrow \mathrm{Fe}^{+2} \mathrm{O}+\mathrm{H}_{2} \mathrm{O} \\
& \mathrm{Fe}^{+2}+\mathrm{Fe}^{+2}-\mathrm{O}_{2} \rightarrow \mathrm{Fe}^{+2}-\mathrm{O}_{2}-\mathrm{Fe}^{+2} \rightarrow 2 \mathrm{Fe}^{+2}-\mathrm{O}_{2}
\end{aligned}
$$

Lipid (LH) peroxidation is performed by the following three steps (52);

$$
\begin{aligned}
& \text { a) Initiation: } \\
& \mathrm{LH}+{ }^{\circ} \mathrm{OH} \rightarrow \mathrm{L} \cdot+\mathrm{H}_{2} \mathrm{O} \\
& \text { b) Propagation: } \\
& \mathrm{L} \cdot+\mathrm{O}_{2} \rightarrow \mathrm{LOO} \cdot \\
& \mathrm{LOO}+\mathrm{LH} \rightarrow \mathrm{L} \cdot+\mathrm{LOOH} \\
& \mathrm{LOOH} \rightarrow \mathrm{LO}+{ }^{-O H} \\
& \text { c) Termination: } \\
& \mathrm{L} \cdot+\mathrm{L} \cdot \rightarrow \mathrm{L}-\mathrm{L} \\
& \mathrm{L} \cdot+\mathrm{LOO} \cdot \rightarrow \mathrm{LOOL} \\
& \mathrm{LOO}+\mathrm{LOO} \cdot \rightarrow \mathrm{LOOL}+\mathrm{O}_{2}
\end{aligned}
$$

Transition metals such as copper and iron can act as a positive catalyst in initiation and propagation steps of lipid peroxidation.

$$
\begin{aligned}
& \mathrm{Cu}^{+}+\mathrm{LOOH} \rightarrow \mathrm{LO}+{ }^{-} \mathrm{OH}+\mathrm{Cu}^{+2} \\
& \mathrm{Cu}^{+2}+\mathrm{LOOH} \rightarrow \mathrm{LOO}^{+}+\mathrm{Cu}^{+}
\end{aligned}
$$$$
2 \mathrm{LOOH} \rightarrow \mathrm{LO}+\mathrm{LOO}+\mathrm{H}_{2} \mathrm{O}
$$ 
Polyunsaturated fatty acids (PUFAs) are mainly targeted by these radicals due to the presence of double bonds and produce polyunsaturated fatty acid-free radicals ( $\left.\mathrm{LO}^{\circ}, \mathrm{LOO}^{\circ}\right)$. Malondialdehyde (MDA) is then produced by the cyclization reaction of end peroxides and peroxyl radicals (ROO') (53, 54). 4-hydroxy-2-nonenal (HNE) and malondialdehyde (MDA) as lipid peroxidation products are formed in mitochondria (55).

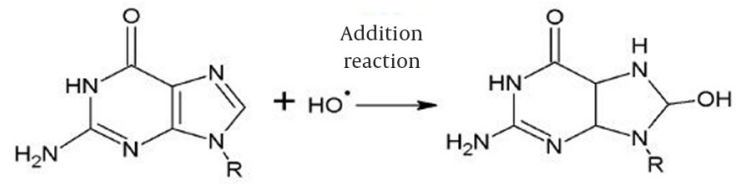

Desoxy-guanosine

8-hydroxy-desoxy-guanosine

Figure 1. OH + DNA $\rightarrow$ DNA Strand Breaks [Hydrogen Abstraction]

\subsection{Protein Oxidation}

Free amino acids and proteins are oxidized to corresponding aldehyde and carboxylic acid by hydroxyl and superoxide radicals (56) produced by the Fenton and Haber-Weiss reaction and are known as "metal-catalyzed-oxidation" (MCO) (57). Oximes are also produced by hydrogen peroxide and the reaction is initiated by abstraction of $\alpha-\mathrm{H}$ of amino acid by $\bullet \mathrm{OH}$ and carboncentered radical is formed, which reacts with superoxide radical, hydrogen peroxide and water, to produce carboxylic acid and aldehyde. The overall reaction is represented in Figure 2.

Oxidation of cysteine residues leads to the reversible formation of mixed disulfides between protein thiol groups and low molecular weight thiol, in particular GSH (56). Carbonyl groups are produced by protein oxidation with ROS (58). Protein oxidation is catalyzed by $\mathrm{Fe}, \mathrm{Cu}$, and $\mathrm{Al}$ with $\mathrm{H}_{2} \mathrm{O}_{2}$.i.e. the Fenton-type reaction.

\subsection{Advanced Glycation End (AGEs) Formation}

The Fenton and Haber-Weiss reactions play significant role in the formation of advanced glycation end products with $\mathrm{OH}$-acting as a base. Aldehyde (-CHO) or ketone $(-\mathrm{C}=\mathrm{O})$ containing compounds such as glucose can react with amino group (- $\left.\mathrm{NH}_{2}\right)$ of proteins forming the "Schiff's base". Then the "Schiff's base" rearranges to produce the "Amadori products" (Figure 3). These products are responsible for the formation of advanced Glycation end-products (AGEs) through several types of reactions, such as rearrangement, dehydration, condensation, fragmentation, oxidation and cyclization reactions (59).

High reactive carbonyl intermediates such as glyoxal, 3-deoxy-glucosome and methyl-glyoxal are produced by auto-oxidation of glucose, the Schiff's base or the Amadori products. Then these products can also react with protein free amino group and produce imidazolone, $\mathrm{N}$ q-carboxy-methyl-lysine (CML), N-q-carboxy-ethyl-lysine (CEL), glyoxal-lysine dimer (GOLD) and methyl-glyoxallysine dimer (MOLD) (60-64). AGEs accumulate both intra and extracellular of the aging brain, but in case of AD brain, more AGEs are found in plaque fractions responsible for $A \beta$, than control brain (65).

\subsection{Effect of ROS on Signaling Pathways}

ROS is mainly produced by the Fenton and Haber-Weiss reactions and excess ROS can cause cell death through apoptosis in AD (66). ROS and A $\beta$ can activate ASK1 signaling pathway. ASK1 activates "ASK1 Signalosome" by TNF receptor-associated factor (TRAF) 2 and 6 (67). Then it activates MKK 3/6 pathways, as a result JNK signaling pathway is activated leading to insulin resistance by serine phosphorylation of insulin receptor substrate 1 (IRS 1). Brain imaging (68) revealed the presence of hypoglycemia in Alzheimer's disease (69-71). Glucose metabolism is regulated mainly by insulin signaling (72), but little is known about the role of insulin in the brain (73). JNK pathway can activate tau phosphorylation and neuronal cell-death (74) as well as inhibiting tyrosine phosphorylation of IRS-1, which results in further cognitive impairment in $\mathrm{AD}$.

\section{Results}

It is now well established that ROS and RNS (Table 1) can damage different targeted biological molecules such as DNA, protein, lipid through Fenton gated oxidative stress. Figure 4 exhibits synergistic activity of iron and aluminum. Here we can see reduction of $\mathrm{Fe}^{3+}$ to $\mathrm{Fe}^{2+}$ by $\mathrm{AlO}_{2}{ }^{2+}$, which promotes the oxidative stress through Fenton and Haber-Weiss reaction. Similarly, signaling molecules play essential role in conjunction with Fenton reaction in the pathogenesis of $\mathrm{AD}$ as shown in Figure 5.

\section{Discussion}

Mitochondrial dysfunction has a pivotal role in $\mathrm{Al}$ zheimer's disease. Production of reactive oxygen species is one of the main reasons of mitochondrial dysfunction. ROS can damage protein, lipid, DNA and can impair glucose metabolism, which is interlinked with insulin signaling. Therefore, there could be an association between Alzheimer's disease and diabetes mellitus. The Fenton and Haber-Weiss reaction should be focused for the treatment of neurodegenerative diseases such as Alzheimer's disease. Antioxidants, metal chelators and free radical scavengers are used for the treatment of $A D$, but new therapeutic medications could be developed for prevention and treatment of Fenton gated neurological disorders like AD. 
Figure 2. General Reaction Between Amino Acid and ROS Producing Hydroxyl Radical, Superoxide Anion Radical (or Its Conjugated Acid, HO ${ }_{2}{ }^{\text {), Hydro- }}$ gen Peroxide by Fenton and Haber-Weiss Reaction.

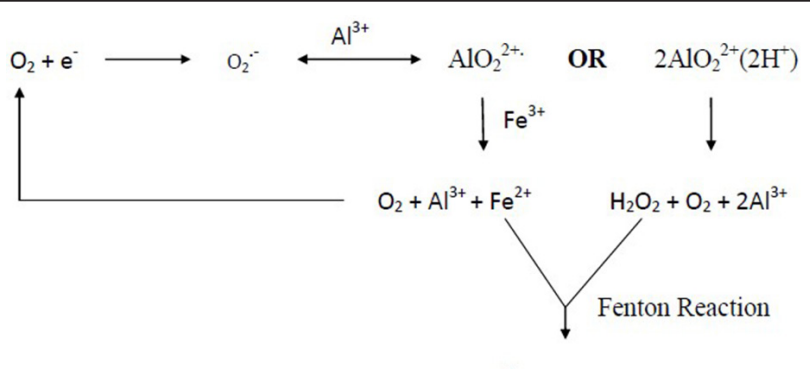

$$
\mathrm{Fe}^{3+}+\cdot \mathrm{OH}+{ }^{-} \mathrm{OH}
$$

In conclusion protein is converted into corresponding aldehyde, carboxylic acid and oxime by oxidation process.

Figure 3. The Mechanism of Amadori Rearrangement

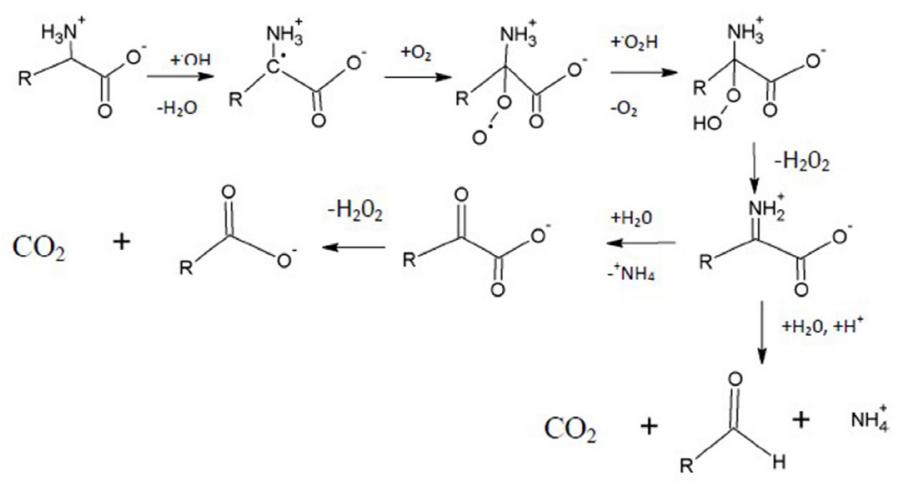

$\mathrm{RCHNH} \mathrm{COO}^{-}+2 \mathrm{H}_{2} \mathrm{O}_{2} \rightarrow \mathrm{RCH}=\mathrm{NOH}+\mathrm{CO}_{2}+3 \mathrm{H}_{2} \mathrm{O}$

Oxime

Amadori product gains their stability by Enol-keto tautomerism. Here-OH acts as a base in this rearrangement.-OH is produced by The Fenton and HaberWeiss reaction. Six types of AGEs are produced as glucose (AGE-1), carbohydrates like glyceraldehydes (AGE-2), dicarbonyls like glycolaldehyde (AGE-3), methylglyoxal (AGE-4), glyoxal (AGE-5) and 3-deoxyglucosone (AGE-6) (60).

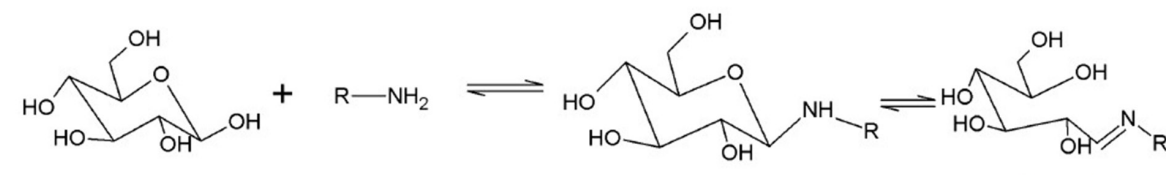

\section{Schiff's base}

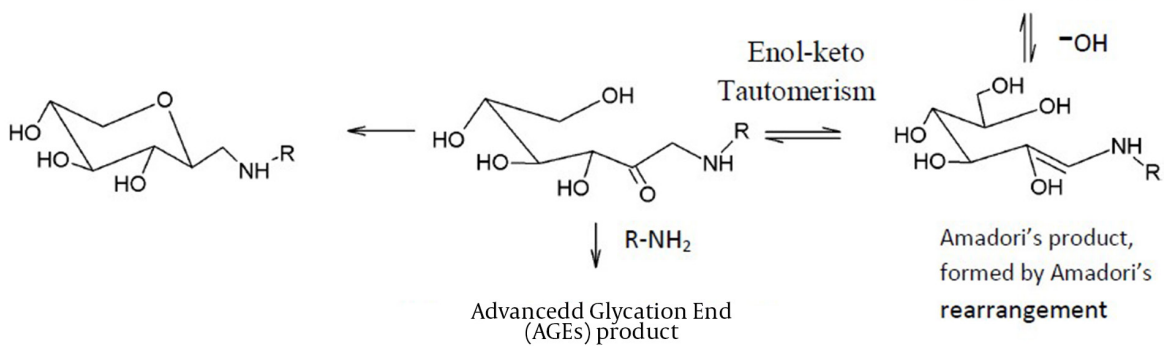

Figure 4. Schematic Diagram for the Formation of Aluminum Superoxide Semireduced Radical Ion and Aluminum Superoxide Complex (43), Which Reduces $\mathrm{Fe}^{3+}$ to $\mathrm{Fe}^{2+}$ and Promotes Oxidative Stress by Hydroxyl Radical Formation Through the Fenton and Haber-Weiss Reaction. 
Figure 5. Schematic Diagram of the ROS and RNS Production and Their Connectivity With ASK1, MKK and JNK Signaling Pathway, adopted from (66).

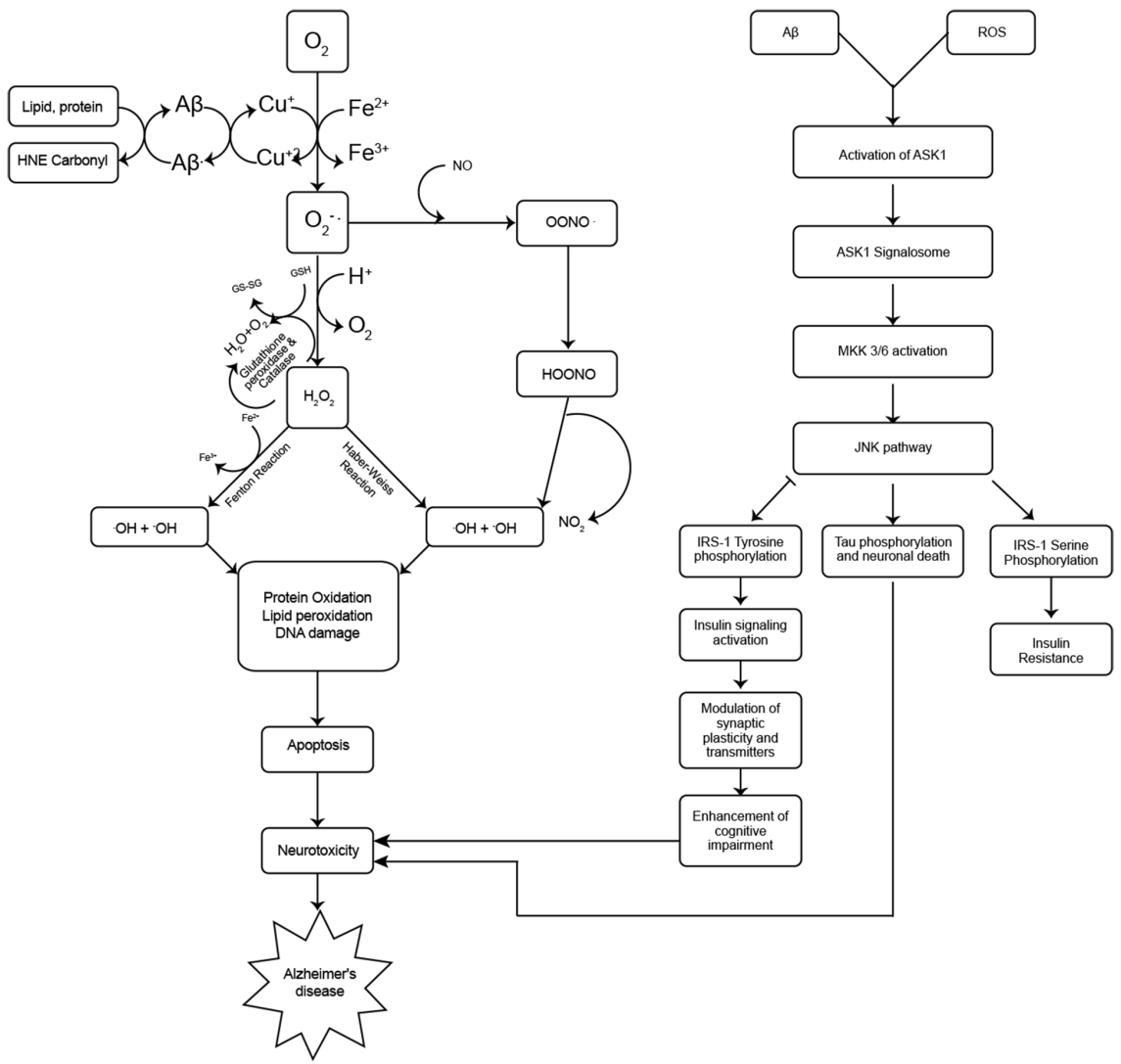

These pathways may create Insulin resistance and Alzheimer's disease. ASK1 activates JNK and in a Raf-independent fashion in response to oxidative stress.

Table 1. Reactive Oxygen and Nitrogen Species Which Enhance Oxidative Stress in Alzheimer's disease (AD); Fe, Cu, Zn and Al Have Catalytic Activity for ROS Production by the Fenton and Haber-Weiss Reaction

\begin{tabular}{|c|c|}
\hline Variable & Value \\
\hline \multicolumn{2}{|l|}{ A) Reactive oxygen spices(ROS) } \\
\hline Type & Symbol \\
\hline \multicolumn{2}{|l|}{ Radical } \\
\hline Superoxide (anion) & $\mathrm{O}_{2}^{\bullet-}$ \\
\hline Carbonate (anion) & $\mathrm{CO}_{3} \cdot-$ \\
\hline Hydroperoxy & $\mathrm{HOO}^{\bullet}$ \\
\hline Hydroxyl & $\mathrm{HO}$ \\
\hline Hydroperoxyl & $\mathrm{HO}_{2}^{\bullet}$ \\
\hline Peroxyl & $\mathrm{ROO}^{\bullet}$ \\
\hline Alkoxyl & $\mathrm{RO}^{\bullet}$ \\
\hline \multicolumn{2}{|l|}{ Non-Radical } \\
\hline Hydrogen Peroxide & $\mathrm{H}_{2} \mathrm{O}_{2}$ \\
\hline Singlet Oxygen & ${ }^{1} \mathrm{O}_{2}$ \\
\hline Hypochlorous Acid & $\mathrm{HOCl}$ \\
\hline Ozone & $\mathrm{O}_{3}$ \\
\hline \multicolumn{2}{|l|}{ B) Reactive Nitrogen Spices(RNS) } \\
\hline Type & Symbol \\
\hline \multicolumn{2}{|l|}{ Radical } \\
\hline Nitrogen Monoxide & $\bullet \mathrm{NO}$ \\
\hline Nitrogen Dioxide & $\cdot \mathrm{NO}_{2}$ \\
\hline \multicolumn{2}{|l|}{ Non-Radical } \\
\hline Peroxynitrite (anion) & ONOO- \\
\hline Peroxynitrous Acid & $\mathrm{ONOOH}$ \\
\hline Nitrosoperoxycarbonate (anion) & ONOOCOO- \\
\hline Nitronium (Cation) & ${ }^{+} \mathrm{NO}^{2}$ \\
\hline Dinitrogen Trioxide & $\mathrm{N}_{2} \mathrm{O}_{3}$ \\
\hline
\end{tabular}




\section{Author's contributions}

First author; acquisition of data/reference papers and primary drafting of the manuscript, second author; administrative technical and material support and study supervision, corresponding author; mainly study concept and design, critical revision of the manuscript, analysis and interpretation and organization of data, final drafting of the manuscript and study supervision.

\section{Financial disclosure}

There was no financial disclosure for this review article.

\section{Funding/Support}

Alzheimer's disease project was funded by the Universiti Brunei Darussalam/Brunei Research Council-2(UBD / BRC-2) Ruj: JPKE/DG/83 (PhD student Tushar Kanti Das was supported by the BRC-2 grant). Brunei Research Council was the granting body for $\mathrm{AD}$ project.

\section{References}

1. Rival T, Page RM, Chandraratna DS, Sendall TJ, Ryder E, Liu B, et al. Fenton chemistry and oxidative stress mediate the toxicity of the beta-amyloid peptide in a Drosophila model of Alzheimer's disease. Eur J Neurosci. 2009;29(7):1335-47.

2. Everett J, Cespedes E, Shelford LR, Exley C, Collingwood JF, Dobson J, et al. Ferrous iron formation following the co-aggregation of ferric iron and the Alzheimer's disease peptide beta-amyloid (1-42). J R Soc Interface. 2014;11(95):20140165.

3. Lipinski B. Is it oxidative or free radical stress and why does it matter. Oxid Antioxid Med Sci. 2012;1(1):1.

4. Birben E, Sahiner UM, Sackesen C, Erzurum S, Kalayci O. Oxidative stress and antioxidant defense. World Allergy Organ J. 2012;5(1):919.

5. Salvador GA, Uranga RM, Giusto NM. Iron and mechanisms of neurotoxicity. Int J Alzheimers Dis. 2010;2011:720658.

6. Dorszewska J, Różycka A, Oczkowska A, Florczak-Wyspiańska J, Prendecki M, Dezor M, et al. Mutations of TP53 Gene and Oxidative Stress in Alzheimer's Disease Patients. ADAPT. 2014;3(1):24-32.

7. Dikalov S, Griendling KK, Harrison DG. Measurement of reactive oxygen species in cardiovascular studies. Hypertension. 2007;49(4):717-27.

8. Buetler TM, Krauskopf A, Ruegg UT. Role of superoxide as a signaling molecule. News Physiol Sci. 2004;19:120-3.

9. Massey V.Activation of molecular oxygen by flavins and flavoproteins. J Biol Chem.1994;269(36):22459-62.

10. Chaiyen P, Fraaije MW, Mattevi A. The enigmatic reaction of flavins with oxygen. Trends Biochem Sci. 2012;37(9):373-80.

11. Shad Kaneez F, Khalid A. In vitro effects of hypolipidemic drugs on oxidative stress. Proc Physiolo Sci J. 2013;44:89-90.

12. Saima G, Sagheer A, Humaira G, Fatima KS. The antioxidant potential of Brassica rapa L. on glutathione peroxidase, superoxide dismutase enzymes and total antioxidant status. rrml. 2013;21(2):161-9.

13. Fatima-Shad K. Investigating the Protective Effect of Solanum melongena. Asian J Health Clin Res. 2011;1(1):276-94

14. Ashraf SS, Rao MV, Kaneez FS, Qadri S, Al-Marzouqi AH, Chandranath IS, et al. Nigella sativa extract as a potent antioxidant for petrochemical-induced oxidative stress. J Chromatogr Sci. 2011;49(4):321-6.

15. Fatima Shad K. Apo lipoprotein E4 gene APOE4: An early predictor of Dementia / Alzheimer's disease. Scientific research and essay. 2013;8(29):1374-9.

16. Nawaz R, Zahir E, Fatima Shad K. Rhodium Interaction with Human NRG1 Gene of Schizophrenia. JPAIR Multidisciplinary Re- search. 2012;7(1).

17. Saeed SA, Shad KF, Saleem T, Javed F, Khan MU. Some new prospects in the understanding of the molecular basis of the pathogenesis of stroke. Exp Brain Res. 2007;182(1):1-10.

18. Shad KF, Aghazadeh Y, Ahmad S, Kress B. Peripheral markers of Alzheimer's disease: surveillance of white blood cells. Synapse. 2013;67(8):541-3.

19. Shad Kaneez F, NurulBahria O. , Aghazadah Y, Sagheer A., Bodo K. . Early diagnosis of Alzheimer's disease in the brain stem nuclei using MR spectroscopy. Scit Neuros Conferenc J. 2013.

20. Aghazadeh Y, Paulose V, Sagheer A, Shad Kaneez F, Quirbach A. HMR-Spectroscopy of inferior colliculus as a tool for early diagnosis of Alzheimer disease in a feasibility study.Germany: Frankfurt.

21. Shad Kaneez F, Khalid A. Barcelona Spain Effects of Statins on Memory. FENS Forum Abstr. 2012

22. Lovell MA, Robertson JD, Teesdale WJ, Campbell JL, Markesbery WR. Copper, iron and zinc in Alzheimer's disease senile plaques. J Neurol Sci.1998;158(1):47-52.

23. Mantyh PW, Ghilardi JR, Rogers S, DeMaster E, Allen CJ, Stimson ER, et al. Aluminum, iron, and zinc ions promote aggregation of physiological concentrations of beta-amyloid peptide. J Neurochem. 1993;61(3):1171-4.

24. Yamamoto A, Shin RW, Hasegawa K, Naiki H, Sato H, Yoshimasu F, et al. Iron (III) induces aggregation of hyperphosphorylated tau and its reduction to iron (II) reverses the aggregation: implications in the formation of neurofibrillary tangles of Alzheimer's disease. J Neurochem. 2002;82(5):1137-47.

25. Hureau C, Faller P. Abeta-mediated ROS production by $\mathrm{Cu}$ ions: structural insights, mechanisms and relevance to Alzheimer's disease. Biochimie. 2009;91(10):1212-7.

26. Huang X, Cuajungco MP, Atwood CS, Hartshorn MA, Tyndall JD, Hanson GR, et al. $\mathrm{Cu}(\mathrm{II})$ potentiation of alzheimer abeta neurotoxicity. Correlation with cell-free hydrogen peroxide production and metal reduction. J Biol Chem. 1999;274(52):37111-6.

27. Maurer I, Zierz S, Moller HJ. A selective defect of cytochrome c oxidase is present in brain of Alzheimer disease patients. Neurobiol Aging. 2000;21(3):455-62.

28. Boll MC, Alcaraz-Zubeldia M, Montes S, Rios C. Free copper, ferroxidase and SOD1 activities, lipid peroxidation and $\mathrm{NO}(\mathrm{x})$ content in the CSF. A different marker profile in four neurodegenerative diseases. Neurochem Res. 2008;33(9):1717-23.

29. Connor JR, Tucker P, Johnson M, Snyder B. Ceruloplasmin levels in the human superior temporal gyrus in aging and Alzheimer's disease. Neurosci Lett.1993;159(1-2):88-90.

30. Markesbery WR. Oxidative stress hypothesis in Alzheimer's disease. Free Radic Biol Med.1997;23(1):134-47.

31. Multhaup G, Schlicksupp A, Hesse L, Beher D, Ruppert T, Masters $\mathrm{CL}$, et al. The amyloid precursor protein of Alzheimer's disease in the reduction of copper(II) to copper(I). Science. 1996;271(5254):1406-9.

32. Ma Q, Li Y, Du J, Liu H, Kanazawa K, Nemoto T, et al. Copper binding properties of a tau peptide associated with Alzheimer's disease studied by CD, NMR, and MALDI-TOF MS. Peptides. 2006;27(4):841-9.

33. Cuajungco MP, Goldstein LE, Nunomura A, Smith MA, Lim JT, Atwood CS, et al. Evidence that the beta-amyloid plaques of $\mathrm{Al}-$ zheimer's disease represent the redox-silencing and entombment of abeta by zinc. J Biol Chem. 2000;275(26):19439-42.

34. Butterfield DA, Castegna A, Lauderback CM, Drake J. Evidence that amyloid beta-peptide-induced lipid peroxidation and its sequelae in Alzheimer's disease brain contribute to neuronal death. Neurobiol Aging. 2002;23(5):655-64

35. Pogocki D. Alzheimer's beta-amyloid peptide as a source of neurotoxic free radicals: the role of structural effects. Acta Neurobiol Exp (Wars). 2003;63(2):131-45.

36. Bush AI, Pettingell WH, Multhaup G, d Paradis M, Vonsattel JP, Gusella JF, et al. Rapid induction of Alzheimer A beta amyloid formation by zinc. Science. 1994;265(5177):1464-7.

37. Lim KH, Kim YK, Chang YT. Investigations of the molecular mechanism of metal-induced Abeta (1-40) amyloidogenesis. Biochemistry. 2007;46(47):13523-32.

38. Talmard C, Guilloreau L, Coppel Y, Mazarguil H, Faller P. Amyloidbeta peptide forms monomeric complexes with $\mathrm{Cu}(\mathrm{II})$ and $\mathrm{Zn}(\mathrm{II})$ 
prior to aggregation. Chembiochem. 2007;8(2):163-5.

39. Cuajungco MP, Faget KY. Zinc takes the center stage: its paradoxical role in Alzheimer's disease. Brain Res Brain Res Rev. 2003;41(1):44-56.

40. Khan A, Dobson JP, Exley C. Redox cycling of iron by Abeta42. Free Radic Biol Med. 2006;40(4):557-69.

41. Ruiperez F, Mujika JI, Ugalde JM, Exley C, Lopez X. Pro-oxidant activity of aluminum: promoting the Fenton reaction by reducing $\mathrm{Fe}(\mathrm{III})$ to $\mathrm{Fe}(\mathrm{II})$.J Inorg Biochem. 2012;117:118-23.

42. Exley C. The pro-oxidant activity of aluminum. Free Radic Biol Med. 2004;36(3):380-7.

43. Exley $\mathrm{C}$. The coordination chemistry of aluminium in neurodegenerative disease. Coordina Chmst Rev. 2012;256(19-20):2142-6.

44. Castellani RJ, Honda K, Zhu X, Cash AD, Nunomura A, Perry G, et al. Contribution of redox-active iron and copper to oxidative damage in Alzheimer disease. Ageing Res Rev. 2004;3(3):319-26.

45. Shibutani S, Takeshita M, Grollman AP. Insertion of specific bases during DNA synthesis past the oxidation-damaged base 8-oxodG. Nature.1991;349(6308):431-4.

46. Halliwell B, Gutteridige JMC. Free radicals in biology and medicine. 3 edNew York: Oxford University; 1999.

47. Kreutzer DA, Essigmann JM. Oxidized, deaminated cytosines are a source of C $-\rightarrow$ T transitions in vivo. Proc Natl Acad Sci U S A. 1998;95(7):3578-82.

48.

49. Gajewski E, Rao G, Nackerdien Z, Dizdaroglu M. Modification of DNA bases in mammalian chromatin by radiation-generated free radicals. Biochemistry. 1990;29(34):7876-82.

50. Lyras L, Cairns NJ, Jenner A, Jenner P, Halliwell B. An assessment of oxidative damage to proteins, lipids, and DNA in brain from patients with Alzheimer's disease. J Neurochem. 1997;68(5):2061-9.

51. Gardner HW. Oxygen radical chemistry of polyunsaturated fatty acids. Free Radic Biol Med. 1989;7(1):65-86.

52. Marnett LJ. Lipid peroxidation-DNA damage by malondialdehyde. Mutat Res. 1999;424(1-2):83-95.

53. Marnett LJ. Oxyradicals and DNA damage. Carcinogenesis 2000;21(3):361-70.

54. Chen JJ, Yu BP. Alterations in mitochondrial membrane fluidity by lipid peroxidation products. Free Radic Biol Med.1994;17(5):411-

55. Stadtman ER. Role of oxidant species in aging. Curr Med Chem 2004;11(9):1105-12.

56. Stadtman ER. Oxidation of free amino acids and amino acid residues in proteins by radiolysis and by metal-catalyzed reactions. Annu Rev Biochem. 1993;62:797-821.

57. Valko M, Leibfritz D, Moncol J, Cronin MT, Mazur M, Telser J. Free radicals and antioxidants in normal physiological functions and human disease. Int J Biochem Cell Biol. 2007;39(1):44-84.
58. Grillo MA, Colombatto S. Advanced glycation end-products (AGEs): involvement in aging and in neurodegenerative diseases. Amino Acids. 2008;35(1):29-36.

59. Takeuchi M, Kikuchi S, Sasaki N, Suzuki T, Watai T, Iwaki M, et al. Involvement of advanced glycation end-products (AGEs) in Alzheimer's disease. Curr Alzheimer Res. 2004;1(1):39-46.

60. Takeuchi M, Yanase Y, Matsuura N, Yamagishi Si S, Kameda Y, Bucala R, et al. Immunological detection of a novel advanced glycation end-product. Mol Med. 2001;7(11):783-91.

61. Thornalley PJ, Langborg A, Minhas HS. Formation of glyoxal, methylglyoxal and 3-deoxyglucosone in the glycation of proteins by glucose. Biochem J.1999;344 Pt 1:109-16.

62. Miyata T, Horie K, Ueda Y, Fujita Y, Izuhara Y, Hirano H, et al Advanced glycation and lipidoxidation of the peritoneal membrane: respective roles of serum and peritoneal fluid reactive carbonyl compounds. Kidney Int. 2000;58(1):425-35.

63. Basta G, Schmidt AM, De Caterina R. Advanced glycation end products and vascular inflammation: implications for accelerated atherosclerosis in diabetes. Cardiovasc Res. 2004;63(4):582-92.

64. Picklo MJ, Olson SJ, Markesbery WR, Montine TJ. Expression and activities of aldo-keto oxidoreductases in Alzheimer disease. Neuropathol Exp Neurol. 2001;60(7):686-95.

65. Song J, Park KA, Lee WT, Lee JE. Apoptosis signal regulating kinase 1 (ASK1): potential as a therapeutic target for Alzheimer's disease. Int J Mol Sci. 2014;15(2):2119-29.

66. Matsuzawa A, Saegusa K, Noguchi T, Sadamitsu C, Nishitoh H, Nagai S, et al. ROS-dependent activation of the TRAF6-ASK1-p38 pathway is selectively required for TLR4-mediated innate immunity. Nat Immunol. 2005;6(6):587-92.

67. Schubert D. Glucose metabolism and Alzheimer's disease. Ageing Res Rev. 2005;4(2):240-57.

68. Jagust W, Gitcho A, Sun F, Kuczynski B, Mungas D, Haan M. Brain imaging evidence of preclinical Alzheimer's disease in normal aging. Ann Neurol. 2006;59(4):673-81.

69. Mosconi L, De Santi S, Li J, Tsui WH, Li Y, Boppana M, et al. Hippocampal hypometabolism predicts cognitive decline from normal aging. Neurobiol Aging. 2008;29(5):676-92.

70. Nordberg A, Rinne JO, Kadir A, Langstrom B. The use of PET in Alzheimer disease. Nat Rev Neurol. 2010;6(2):78-87.

71. Bevan P. Insulin signalling.J Cell Sci. 2001;114(Pt 8):1429-30.

72. Cohen E, Dillin A. The insulin paradox: aging, proteotoxicity and neurodegeneration. Nat Rev Neurosci. 2008;9(10):759-67.

73. Kadowaki $\mathrm{H}$, Nishitoh $\mathrm{H}$, Urano F, Sadamitsu C, Matsuzawa A Takeda K, et al. Amyloid beta induces neuronal cell death through ROS-mediated ASK1 activation. Cell Death Differ. 2005;12(1):19-24.

74. Hsu MJ, Hsu CY, Chen BC, Chen MC, Ou G, Lin CH. Apoptosis signal-regulating kinase 1 in a myloid beta peptide-induced cerebral endothelial cell apoptosis. J Neurosci. 20 07;27(21):5719-29. 